\title{
Review of 'plant available water' aspects of water use efficiency under irrigated and dryland conditions
}

\author{
M Hensley ${ }^{1}$, ATP Bennie ${ }^{1}$, LD van Rensburg ${ }^{1 *}$ and JJ Botha ${ }^{2}$ \\ ${ }^{1}$ Department of Soil, Crop and Climate Sciences, University of the Free State, PO Box 339, Bloemfontein 9300, South Africa \\ ${ }^{2}$ ARC Institute for Soil, Climate and Water, PO Box 26448, Langenhoven Park, Bloemfontein, 9331, South Africa
}

\begin{abstract}
This review provides an overview of Water Research Commission (WRC)-funded research over the past 36 years. A total of 28 WRC reports have been consulted, 13 of these compiled by the University of the Free State, 4 by the University of Fort Hare, and the remainder mainly by the ARC-Institute for Soil Climate and Water. This work has resulted in extensive capacity building in this field - numerous technical assistants and 58 researchers have been involved, of which 23 are still active in research.

The focus on the water flow processes in the soil-plant-atmosphere continuum (SPAC), with particular emphasis on processes in the soil, has greatly enhanced understanding of the system, thereby enabling the formulation of a quantitative model relating the water supply from a layered soil profile to water demand; the formulation of logical quantitative definitions for crop-ecotope specific upper and lower limits of available water; the identification of the harmful rootzone development effects of compacted layers in fine sandy soils caused by cultivation, and amelioration procedures to prevent these effects; and management strategies to combat excessive water losses by deep drainage.

The explanation of the way in which SPAC is expressed in the landscape in the form of the ecotope has been beneficial with regard to the extrapolation of studies on particular SPACs to the large number of ecotopes where detailed studies have not been possible. Valuable results are reported regarding rainfall and runoff management strategies. Longer fallow periods and deficit irrigation on certain crop ecotopes improved rainfall use efficiency. On semi-arid ecotopes with high-droughtrisk clay and duplex soils and high runoff losses, in-field rainwater harvesting (IRWH), designed specifically for subsistence farmers, resulted in maize and sunflower yield increases of between $30 \%$ and $50 \%$ compared to yields obtained with conventional tillage.

An indication of the level of understanding of the relevant processes that has been achieved is demonstrated by their quantitative description in mathematical and empirical models: BEWAB for irrigation, SWAMP mainly for dryland cropping, and CYP-SA for IRWH.

Five important related research and development needs are identified.

The WRC has played, and continues to play, an important role in commissioning and funding research on water utilisation in agriculture and has clearly made an excellent contribution to the progress made in addressing the needs and requirements of subsistence, emergent and dryland farmers in South Africa.
\end{abstract}

Keywords: BEWAB, SWAMP, CYP-SA, in-field rainwater harvesting, dryland ecotope, irrigation

\section{Introduction}

This paper is presented in 3 main parts. The overall aim envisages much more than just paying tribute to the excellent work done by many diligent agricultural scientists and their assistants over a period of 36 years, as well as the associated foresight of the Water Research Commission (WRC) in commissioning these projects and providing funding for these research teams.

- The motivation forms the first part of the introduction and explains the importance of the subject, not just for South Africa but also for all parts of the world where food production under semi-arid conditions is difficult.

- In the second part of the paper the soil-plant-atmosphere continuum (SPAC) is defined, together with, firstly, the problems associated with promoting the water use efficiency of the system, and secondly, details about efforts to deal with these problems by agricultural scientists of many disciplines.

This paper was originally presented at the Water Research

Commission 40-Year Celebration Conference, Kempton Park,

31 August - 1 September 2011.

* To whom all correspondence should be addressed.

용 +27 51 401-2957; fax: +27 51 401-2212;

e-mail: vrensbl@ufs.ac.za
- The aim of the third part, consisting of 2 sections, i.e. 'Quantifying the water flow processes in SPAC', and 'Managing rainfall and runoff', is to focus on past research results that serve as signposts for the way ahead. These are considered to be the high-priority aspects that need diligent attention to ensure sufficient food production for an ever-growing population, putting further strain on a natural resource that does not increase in size, and could even decrease drastically in size if not properly cared for.

\section{Motivation}

The following bioclimatic zone definition, with aridity index (AI) defined as mean annual evaporation divided by mean annual rainfall, was presented by UNESCO (1977):

- Hyper-arid zones; virtually no vegetation; unsuitable for agricultural purposes; $\mathrm{AI}<0.03$

- Dry zones with sparse vegetation, only suitable for stock farming and irrigation; AI 0.03 to 0.2

- Semi-arid zones with relatively dense vegetation, and suitable for both stock farming, crop farming with a high risk of crop failure, and irrigation; AI 0.2 to 0.5

- Sub-humid zones with dense vegetation and suitable for intensive stock farming and crop farming with low risk of crop failure; $\mathrm{AI}>0.5$ 
Bennie et al. (1998) present a map (Fig. 1) showing the bioclimatic zones of South Africa using these criteria. The area with $\mathrm{AI}<0.2$ is shown as one unit (dry) on the map and constitutes slightly more than half of South Africa. The sub-humid area

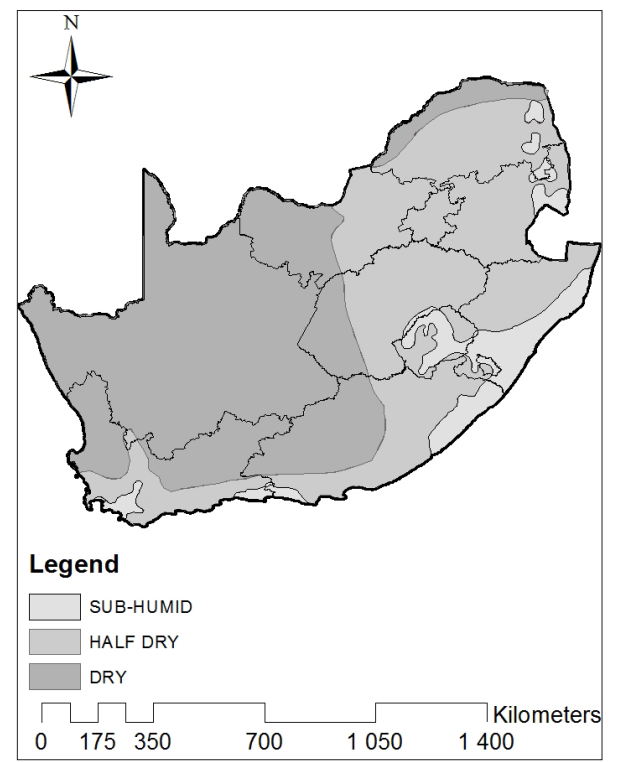

Figure 1

Bioclimatic zones of South Africa (Bennie et al., 1998) with 'low risk of crop failure' is a very small fraction. This map describes in an eloquent way the importance of the subject being reviewed, since its focus is on semi-arid areas, roughly $40 \%$ of South Africa.

Bennie et al. (1994) make another important point about the importance of this subject in the executive summary of their report: 'It is generally accepted that irrigation is the only way to stabilise crop production in dry and semi-arid areas. The ever increasing restriction on the availability of water for irrigation makes it essential to study the stabilisation of dryland crop production, especially during dry years, to ensure the adequate production of food and fibre for a growing population. An additional contributing factor to the worldwide increase in attention to promoting sustainable dryland farming systems is the escalation in the cost of establishing new irrigation schemes and the high cost of maintaining and operating established irrigation schemes.' Rao et al. (2004) recently expressed similar sentiments regarding the growing importance of rain-fed agriculture worldwide. Since much of the irrigation in South Africa is currently done by means of sprinkler systems which require energy for pumping, the recent massive increases in the cost of energy accentuate even further the importance of improving dryland crop production in South Africa.

Tables 1 and 2 list the topics addressed by each WRC project included in this review. They provide a handy guide for anyone interested in a particular topic to find relevant reports.

\begin{tabular}{|c|c|c|c|c|c|c|c|c|c|c|c|c|c|c|}
\hline \multicolumn{15}{|c|}{$\begin{array}{c}\text { Table } 1 \\
\text { Details about the subjects addressed in each WRC report reviewed }\end{array}$} \\
\hline \multirow[t]{2}{*}{ WRC report references } & \multicolumn{6}{|c|}{ Defining and quantifying PAW } & \multicolumn{8}{|c|}{$\begin{array}{l}\text { Management strategies and water balance measurements } \\
\text { made to facilitate decisions }\end{array}$} \\
\hline & \begin{tabular}{|c} 
Crop in \\
Crop \\
water \\
require- \\
ment \\
\end{tabular} & $\begin{array}{l}\text { fluence } \\
\text { Rooting } \\
\text { depth } \\
\text { and } \\
\text { intensity } \\
\end{array}$ & $\begin{array}{c}\text { Climate } \\
\text { influence } \\
\text { (ETo) } \\
y\end{array}$ & \begin{tabular}{|c|} 
Soil \\
profile \\
charac- \\
teristics
\end{tabular} & $\begin{array}{l}\text { Upper } \\
\text { limit }\end{array}$ & $\begin{array}{l}\text { Lower } \\
\text { limit }\end{array}$ & $P$ & $T$ & DS & D & $\mathbf{R}$ & Es & Ev & \begin{tabular}{|c|} 
Crop pro- \\
duction \\
tech- \\
nique
\end{tabular} \\
\hline Burger et al. (1979) & & $\mathrm{X}$ & & & & & & & & & & & & \\
\hline Human et al. (1980) & $\mathrm{X}$ & & & & & & & & & & & & & \\
\hline Hensley and De Jager (1982) & $\mathrm{X}$ & $\mathrm{X}$ & $\mathrm{X}$ & $\mathrm{X}$ & $\mathrm{X}$ & $\mathrm{X}$ & $\mathrm{X}$ & $\mathrm{X}$ & $\mathrm{X}$ & & & $\mathrm{X}$ & $\mathrm{X}$ & $\mathrm{X}$ \\
\hline Russell (1982) & & & & $\mathrm{X}$ & $\mathrm{X}$ & $\mathrm{X}$ & & $\mathrm{X}$ & & $\mathrm{X}$ & & & & $\mathrm{X}$ \\
\hline Botha et al. (1983) & $\mathrm{X}$ & $\mathrm{X}$ & $\mathrm{X}$ & $\mathrm{X}$ & & & $\mathrm{X}$ & $\mathrm{X}$ & $\mathrm{X}$ & & & $\mathrm{X}$ & $\mathrm{X}$ & $\mathrm{X}$ \\
\hline Boedt and Laker (1985) & & $\mathrm{X}$ & & $\mathrm{X}$ & $\mathrm{X}$ & $\mathrm{X}$ & $\mathrm{X}$ & $\mathrm{X}$ & $\mathrm{X}$ & & & & & \\
\hline Nel et al. (1986) & $\mathrm{X}$ & & & & & & & & & & & & & \\
\hline Meyer et al. (1987) & $\mathrm{X}$ & & $\mathrm{X}$ & & & & & & & & & & & \\
\hline Bennie et al. (1988) & $\mathrm{X}$ & $\mathrm{X}$ & & & $\mathrm{X}$ & $\mathrm{X}$ & & $\mathrm{X}$ & & & & & & \\
\hline Dent et al.(1988) & $\mathrm{X}$ & & $\mathrm{X}$ & & & & & $\mathrm{X}$ & & & & & & \\
\hline Vanassche and Laker (1989) & $\mathrm{X}$ & & $\mathrm{X}$ & & $\mathrm{X}$ & $\mathrm{X}$ & & $\mathrm{X}$ & $\mathrm{X}$ & & & & $\mathrm{X}$ & $\mathrm{X}$ \\
\hline Bennie et al. (1994) & $\mathrm{X}$ & $\mathrm{X}$ & $\mathrm{X}$ & $\mathrm{X}$ & $\mathrm{X}$ & $\mathrm{X}$ & $\mathrm{X}$ & & $\mathrm{X}$ & $\mathrm{X}$ & $\mathrm{X}$ & $\mathrm{X}$ & $\mathrm{X}$ & $\mathrm{X}$ \\
\hline Walker et al.(1995) & $\mathrm{X}$ & & & & & & & & & & & & & \\
\hline Bennie et al. (1997) & $\mathrm{X}$ & $\mathrm{X}$ & $\mathrm{X}$ & $\mathrm{X}$ & $\mathrm{X}$ & $\mathrm{X}$ & $\mathrm{X}$ & $\mathrm{X}$ & $\mathrm{X}$ & $\mathrm{X}$ & $\mathrm{X}$ & $\mathrm{X}$ & $\mathrm{X}$ & $\mathrm{X}$ \\
\hline Hensley et al. (1997) & & $\mathrm{X}$ & $\mathrm{X}$ & $\mathrm{X}$ & $\mathrm{X}$ & $\mathrm{X}$ & $\mathrm{X}$ & & $\mathrm{X}$ & $\mathrm{X}$ & $\mathrm{X}$ & $\mathrm{X}$ & $\mathrm{X}$ & \\
\hline Van Zyl and De Jager (1997) & & & & & & & & & & & & $\mathrm{X}$ & $\mathrm{X}$ & \\
\hline Bennie et al. (1998) & $\mathrm{X}$ & $\mathrm{X}$ & $\mathrm{X}$ & $\mathrm{X}$ & $\mathrm{X}$ & $\mathrm{X}$ & $\mathrm{X}$ & $\mathrm{X}$ & $\mathrm{X}$ & $\mathrm{X}$ & $\mathrm{X}$ & $\mathrm{X}$ & $\mathrm{X}$ & $\mathrm{X}$ \\
\hline Hensley et al. (2000) & & $\mathrm{X}$ & $\mathrm{X}$ & $\mathrm{X}$ & $\mathrm{X}$ & $\mathrm{X}$ & $\mathrm{X}$ & & $\mathrm{X}$ & $\mathrm{X}$ & $\mathrm{X}$ & $\mathrm{X}$ & $\mathrm{X}$ & $X$ \\
\hline Van Deventer et al. (2002) & & & & $\mathrm{X}$ & & & & $\mathrm{X}$ & $\mathrm{X}$ & $\mathrm{X}$ & & & & \\
\hline Botha et al. (2003) & & $\mathrm{X}$ & $\mathrm{X}$ & $\mathrm{X}$ & $\mathrm{X}$ & $\mathrm{X}$ & $\mathrm{X}$ & & $\mathrm{X}$ & $\mathrm{X}$ & $\mathrm{X}$ & $\mathrm{X}$ & $\mathrm{X}$ & $\mathrm{X}$ \\
\hline \multicolumn{15}{|l|}{ Ehlers et al. (2003) } \\
\hline Walker and Tsubo (2003) & $\mathrm{X}$ & $\mathrm{X}$ & $\mathrm{X}$ & $\mathrm{X}$ & & & & $\mathrm{X}$ & $\mathrm{X}$ & & & $\mathrm{X}$ & $\mathrm{X}$ & $\mathrm{X}$ \\
\hline Kundhlande et al. (2004) & & & & & & & & & & & & & & $X$ \\
\hline \multicolumn{15}{|l|}{ Ehlers et al. (2007) } \\
\hline \multicolumn{15}{|l|}{ Hensley et al. (2007) } \\
\hline Blignaut and Sibande (2008) & $\mathrm{X}$ & $\mathrm{X}$ & & $\mathrm{X}$ & & & & $\mathrm{X}$ & & & & & & $\mathrm{X}$ \\
\hline Manona and Baiphethi (2008) & & & & $\mathrm{X}$ & & & & & & & & & & $\mathrm{X}$ \\
\hline
\end{tabular}




\section{Defining the system and physical factors needed to promote improved water use efficiency}

This section constitutes the 'second part' referred to in the introduction.

The SPAC, which is the subject of this study, is depicted in Fig. 2 and mathematically described in Eq. (1). The natural resource factors that influence yield, i.e. climate, topography (slope), and soil are represented in the figure. All the processes affecting changes in the soil water content for a given period are incorporated in Eq. (1):

$$
\Delta S=P+I \pm D \pm R-E s-E v
$$

where:

$$
\begin{aligned}
\Delta S= & \text { change in soil water content of the root zone }(\mathrm{mm}) \\
P= & \text { precipitation amount }(\mathrm{mm}) \\
I= & \text { irrigation amount }(\mathrm{mm}) \\
D= & \text { drainage beyond the root zone }(-) \text { or capillary rise } \\
& \text { of water from a water table into the root zone }(+) \\
& (\mathrm{mm}) \\
R= & \text { runoff }(-) \text { or runon }(+) \text { amount }(\mathrm{mm}) \\
E s= & \text { evaporation of soil water }(\mathrm{mm}) \\
E v= & \text { evaporation from the canopy of the crop }(\mathrm{mm})
\end{aligned}
$$

If we imagine a particular SPAC (i.e. particular climate, slope and soil) in 3-dimensional form in the landscape, we have an ecotope as defined by MacVicar et al. (1974). Figure 2 and Eq. (1) are therefore also applicable to an ecotope. Hence the

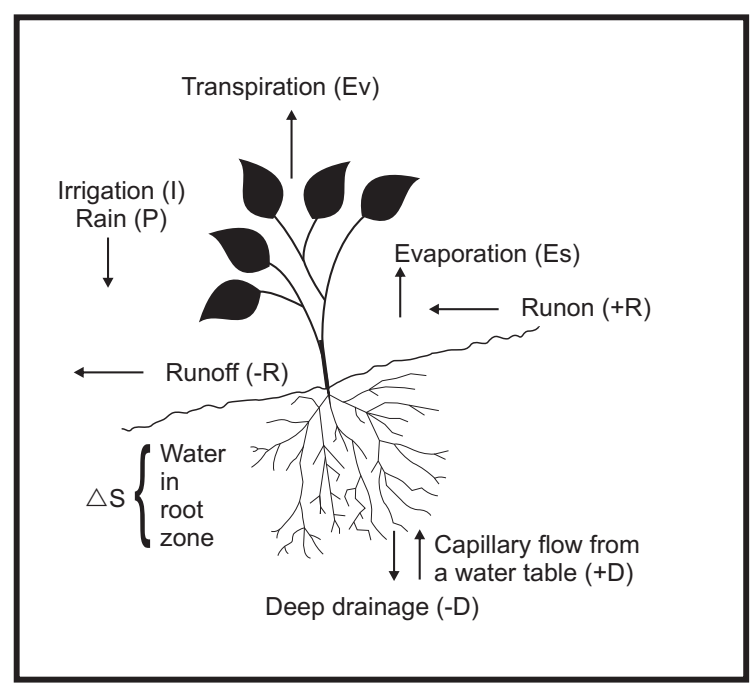

Figure 2

The soil-plant-atmosphere continuum (SPAC) showing the

\begin{tabular}{|c|c|c|c|c|c|c|c|c|c|c|}
\hline \multicolumn{11}{|c|}{$\begin{array}{c}\text { Table } 2 \\
\text { Details about the use of models to facilitate management strategies in each WRC report reviewed }\end{array}$} \\
\hline \multirow{2}{*}{ WRC report references } & \multicolumn{9}{|c|}{ Name of model } & \multirow{2}{*}{$\begin{array}{l}\text { Impact } \\
\text { studies }\end{array}$} \\
\hline & BEWAB & PUTU & DSSAT & SWAMP & $\begin{array}{l}\text { PAWC } \\
\text { Model }\end{array}$ & CYP-SA & ACRU & $\begin{array}{c}\text { PUTU- } \\
\text { RUN }\end{array}$ & SWB & \\
\hline \multicolumn{11}{|l|}{ Burger et al. (1979) } \\
\hline \multicolumn{11}{|l|}{ Human et al. (1980) } \\
\hline Hensley and De Jager (1982) & & & & & $\mathrm{X}$ & & & & & \\
\hline \multicolumn{11}{|l|}{ Russell (1982) } \\
\hline \multicolumn{11}{|l|}{ Botha et al. (1983) } \\
\hline Boedt and Laker (1985) & & & & & $\mathrm{X}$ & & & & & \\
\hline Nel et al. (1986) & $\mathrm{X}$ & & & & & & & & & \\
\hline Meyer et al. (1987) & & & & & & & $\mathrm{X}$ & & & \\
\hline \multicolumn{11}{|l|}{ Bennie et al. (1988) } \\
\hline \multicolumn{11}{|l|}{ Dent et al.(1988) } \\
\hline \multicolumn{11}{|l|}{ Vanassche and Laker (1989) } \\
\hline Bennie et al. (1994) & $\mathrm{X}$ & & & & & & & & & \\
\hline Walker et al.(1995) & & $\mathrm{X}$ & $\mathrm{X}$ & & & & & & & \\
\hline Bennie et al. (1997) & & $\mathrm{X}$ & & & & & & & & \\
\hline Hensley et al. (1997) & & & & $\mathrm{X}$ & & & & & & \\
\hline Van Zyl and De Jager (1997) & & $\mathrm{X}$ & $\mathrm{X}$ & & & & & & & \\
\hline \multicolumn{11}{|l|}{ Bennie et al. (1998) } \\
\hline Hensley et al. (2000) & & & & & & $\mathrm{X}$ & & & & \\
\hline \multicolumn{11}{|l|}{ Van Deventer et al. (2002) } \\
\hline Botha et al. (2003) & & & & & & & & $\mathrm{X}$ & & \\
\hline \multicolumn{11}{|l|}{ Ehlers et al. (2003) } \\
\hline \multicolumn{11}{|l|}{ Walker and Tsubo (2003) } \\
\hline Kundhlande et al. (2004) & & & & & & & & & & $\mathrm{X}$ \\
\hline \multicolumn{11}{|l|}{ Ehlers et al. (2007) } \\
\hline \multicolumn{11}{|l|}{ Hensley et al. (2007) } \\
\hline Blignaut and Sibande (2008) & & & & & & & & & & $X$ \\
\hline Manona and Baiphethi (2008) & & & & & & & & & & $X$ \\
\hline
\end{tabular}
water-balance processes. An appropriate form of the water balance equation for the system is presented as Eq. (1).

appropriateness of the title of the report: 'The use of computer models for agricultural water management at ecotope level', published by Bennie et al. (1998). Of note is the significance of the first sentence of its foreword: 'The results of 22 years of research have been summarised in this report in the form of a computer programme'. The value of a computer program in which the SPAC/ecotope water balance processes have been 
reliably quantified in mathematical terms lies in the ability of the model to be used effectively to extrapolate research results obtained at a few benchmark ecotopes to the vast number of ecotopes where it has not been possible to do research. The application of this objective by other WRC research teams is expressed in Table 2 by the fact that 8 of the 9 models listed there are mainly the result of projects all focusing to some extent on the water balance of ecotopes.

Understanding the functioning of the SPAC system, and therefore what is needed to promote improved water use efficiency, can be improved by simplifying Eq. (1) in a logical way that is relevant to specific kinds of ecotopes. For a dryland crop ecotope in a semi-arid area, with a fairly deep mediumtextured soil that is well protected against excessive runoff by contouring, it is valid for most seasons to rewrite Eq. (1) as:

$$
\Delta S=P-E S-E v
$$

Under the specified conditions, since the magnitude of Ev is directly related to yield, and the fact that we cannot control $\mathrm{P}$, what we need to do is minimise $E s$ and maximise $\Delta S$ by selecting suitable deep soils (large $\Delta S$ ), deep-rooted drought-resistant crops (large $\Delta S$ ), and eliminating any factors that impair root development. Numerous statements in WRC research reports express the efforts required to deal with these problems. For example, in Van Zyl and De Jager (1997): 'any water evaporated through the soil surface is wasted because it does not contribute to producing crop biomass. Hence for the management of scarce water resources, an accurate mathematical simulation of plant and soil evaporation is required.' In Bennie et al. (1994) it is stated that one of the objectives of the project was to measure the impact of different production strategies aimed at promoting the efficient storage of water in the root zone. One of the strategies studied was the use of plant residues as surface mulches to reduce $E S$, while another used a long fallow period aimed at getting $\Delta S$ as large as possible at planting. For the infield rainwater harvesting (IRWH) crop-production technique (Hensley et al., 2000; Botha et al., 2003) sunflower, a droughtresistant crop, gave good results. It is furthermore shown that for IRWH to be successful soils need to be deep and have a good water holding capacity (large $\Delta S$ ).

Studies by Botha et al. (1983) showed that soils high in fine sand (Annandale series) at Vaalharts tend to develop compacted layers when cultivated. Their solution to the problem was expressed as follows: 'for both maize and wheat the deep cultivation resulted in larger and deeper root systems which were more efficient, in respect of water use and yield, than those of control treatments'. Although their study was focused on an irrigated soil, the process of compaction on these soils also occurs under dryland cropping.

Whether considering Fig. 2 to represent an irrigated or a dryland ecotope, there are certain principles that apply to both situations. An important one involves the signal that the crop gives to show that $\Delta S$ is becoming depleted. The following WRC reports present research results in this connection: Human et al. (1980); Hensley and de Jager (1982); Botha et al. (1983); Boedt and Laker (1985); Nel et al. (1986); Meyer et al. (1987); Bennie et al. (1988); Vanassche and Laker (1989); Walker et al. (1995); Bennie et al. (1997); Bennie et al. (1998).

With regard to providing information about crop water requirements for irrigation planning ( $E v$ and $I$ in Fig. 2 and Eq. (1)) for the whole of South Africa, the contribution made by Dent et al. (1988) is remarkable. A total of 712 homogeneous climate zones were identified and the boundaries of each one digitised, enabling them to be mapped at any scale. Furthermore, estimates of crop water requirements under irrigated conditions were provided for each zone.

The results of projects concerned with the management of unproductive drainage losses (-D in Fig. 2 and Eq. (1)) are presented in the following reports: Bennie et al. (1988); Vanassche and Laker (1989); Bennie et al. (1994); Bennie et al. (1997).

The main findings were that:

- For dryland crop production it was advantageous to select soils with a high $\Delta S$ value, e.g. soils with a restricting layer below the root zone

- For irrigated crop production the scheduling method should make allowance for rain storage to cater for possible rain events between irrigations, with deficit irrigation being a feasible strategy under certain conditions.

Results of projects dealing with the management of productive drainage losses ( $-D$ in Fig. 2) are presented in the WRC report compiled by Ehlers et al. (2007). Information is presented regarding the extent of over-irrigation required to achieve the necessary leaching requirement, and also when necessary, to remove excess salts from the root zone.

The management of capillary rise gains of water from shallow water tables into the root zone ( $+D$ in Fig. 2 ) was studied in the WRC projects of Ehlers et al. (2003) and Ehlers et al. (2007). They found that this upward flux could supply up to $60 \%$ of crop water demand - very beneficial in dryland crop production, but a process that needed to be carefully managed in irrigated crop production.

Water balance processes designated as $P, R$ and $\Delta S$ in Fig. 2 and Eq. (1) will be dealt with in detail in separate sections of this review.

\section{Quantifying the water flow processes in SPAC}

\section{A water balance model relating the water supplying rate of the root zone to crop water demand}

Although the need for what follows is of particular importance for efficient crop production under irrigation, the principles involved are equally relevant to dryland crop production. When one considers the SPAC diagram in Fig. 2, it is clear that with a large-volume root zone, in which roots are densely ramified and the soil water content is at a high level, the rate of supply $\left(P W V T_{\mathrm{x}}\right)$ from the root zone for a particular day $(x)$ will be adequate to provide the crop with enough water for that day $\left(E v_{x}\right)$ to prevent any stress occurring. As the soil dries, however, $P W V T$ decreases until $E v$ is too low to keep the stomata open, causing a decrease in the rate of photosynthesis and eventually crop yield is affected if the adverse condition is maintained for any length of time. This is the complex process that Bennie et al. (1988) set out to quantify for a number of different crops on a number of different soils. The process is complex because $P W V T$ is in itself a complex system since it consists of the sum of the supply rate from each layer of the root zone, i.e.:

$$
P W V T \mathrm{x}=\sum_{i=1}^{n} L W V T_{\mathrm{i}}
$$

where:

$L W V T_{\mathrm{i}}$ is the water supply rate from layer $i$

Starting from planting, as the root system expands, the entire system expands as more soil layers are added and the volume of $\Delta S$ increases. Additional complications are the following: the 
hydraulic conductivity $(K)$ of the soil in each layer of a particular soil determines the rate at which the water flows towards the roots before it can be taken up; $K$ decreases rapidly as the soil dries; the $K$ curve for each soil layer will probably be different; the intensity of root ramification at any particular growth stage determines the distance over which the water needs to flow to reach the roots; the extent and intensity of root ramification of a particular crop in a particular soil will vary at different growth stages. After making a host of measurements over a number of seasons with a number of crops on a number of soils and consulting a large amount of relevant literature, Bennie et al. (1988) were able to say that 'the potential water supply by a particular soil layer (i) with homogeneous root ramification can be calculated using the following formula'

$$
L W V T_{\mathrm{i}}=F \mathrm{sr}_{\mathrm{i}} \cdot \ln \left({ }^{\theta \mathrm{i}}{ }_{\theta \mathrm{oi}}\right) \cdot\left(\pi L \mathrm{v}_{\mathrm{i}}\right)^{1 / 2} \cdot\left(\phi_{\mathrm{gi}}-\phi_{\mathrm{p}}\right) \cdot \mathrm{z}_{\mathrm{i}}
$$

where:

$$
\begin{array}{ll}
L W V T_{\mathrm{i}}= & \text { water supplying rate by layer } \mathrm{i}\left(\mathrm{mm} \cdot \mathrm{d}^{-1}\right) \\
F \mathrm{sr}_{\mathrm{i}}= & \text { soil-root conductance coefficient for layer } \mathrm{i} \\
& \left(\mathrm{mm}^{2} \cdot \mathrm{d}^{-1} \cdot \mathrm{kPa}^{-1}\right) \\
L \mathrm{v}_{\mathrm{i}}= & \text { rooting density }\left(\mathrm{mm} \text { roots } \mathrm{mm}^{-3} \text { soil) for layer } \mathrm{i}\right. \\
\theta_{\text {oi }}= & \text { volumetric water content at } \phi_{\mathrm{g}}=\phi_{\mathrm{p}} \\
\theta_{\mathrm{i}}= & \text { volumetric water content of layer } \mathrm{i} \\
\phi_{\mathrm{gi}}= & \text { matric potential of layer } \mathrm{i}(\mathrm{kPa}) \\
\phi_{\mathrm{p}}= & \text { leaf xylem potential }(-\mathrm{kPa}) \\
\mathrm{z}_{\mathrm{i}}= & \text { thickness of layer } \mathrm{i}(\mathrm{mm})
\end{array}
$$

They stated furthermore that the summation of $L W V T_{\mathrm{i}}$ over the entire root zone, gives the potential profile water supply rate $\left(P W V T_{\mathrm{x}}\right)$ for a particular day $x$ (Eq. (3)). The crop water stress for the particular day $x$ was defined by means of a stress index, $S I_{x}$, defined as $E v_{x} / P W V T_{\mathrm{x}}$. The onset of crop water stress was considered to occur when $S I$ approached 1, i.e. the value of $P W V T$ for the particular day was approaching the same value as $E v$ for that day, and logically then, when the soil's water supply rate was not able to supply the $E v$ demand, $S I$ would tend to exceed 1. The researchers were satisfied with the results of the project and the calculation procedures were incorporated into the model with the title SWAMP (Soil Water Management Programme) by Bennie et al. (1998).

\section{The upper limit of plant available water}

With regard to quantifying the capacity of the root zone to supply plant available water there are 2 important parameters, i.e. the upper and lower limits of available water. In accord with the original suggestion by Ratliff et al. (1983) the upper limit of available water, derived from in situ measured drainage curves, and termed the drained upper limit (DUL), was adopted by Bennie et al. (1998). The concept was slightly expanded and the exponential equations describing the curves were adapted to be applicable for either a bare soil, $D U L_{\text {bare, }}$ or a cropped soil, $D U L_{\text {crop, }}$ as follows:

$$
\begin{aligned}
& D U L_{\text {bare }}=b-a \ln (a / E s) \\
& D U L_{\text {crop }}=b-a \ln (a / E T)
\end{aligned}
$$

where:

$$
\begin{aligned}
& b=\text { intercept } \\
& a=\text { slope } \\
& E s=\text { soil evaporation }\left(0.1 \mathrm{~mm} \cdot \mathrm{d}^{-1}\right) \\
& E T=\text { mean daily evapotranspiration }\left(\mathrm{mm} \cdot \mathrm{d}^{-1}\right)
\end{aligned}
$$

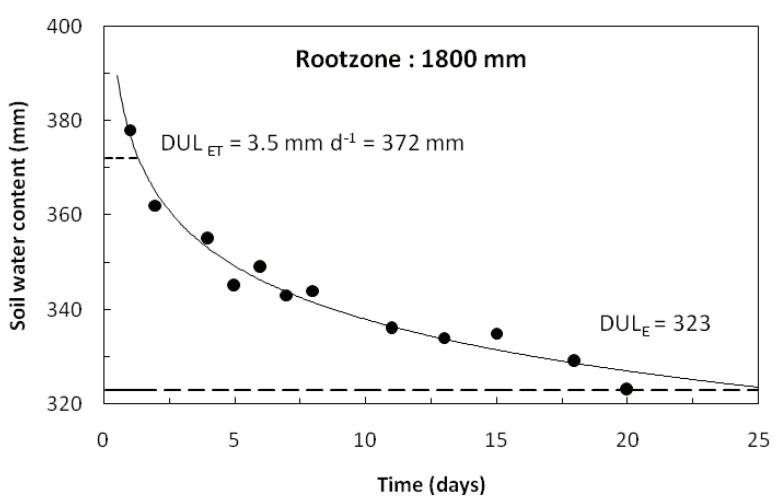

Figure 3

An example of an in situ determined drainage curve of a soil with a crop root zone of $1800 \mathrm{~mm}$ deep. In accordance with Eqs. (4) and (5) it is assumed that Es and ET are $0.1 \mathrm{~mm} \cdot \mathrm{d}^{-1}$ and $3.5 \mathrm{~mm} \cdot \mathrm{d}^{-1}$, respectively, giving the different DUL values shown.

An example of such a curve is presented in Fig. 3.

The $D U L_{\mathrm{ET}}$ value $(372 \mathrm{~mm})$ is much higher than the $D U E_{\mathrm{ES}}$ value $(323 \mathrm{~mm})$ for the following reason: If one adds water to a bare soil that is at $D U L$ the water will drain downwards and at the same time evaporate from the surface at a rate, in this example, of $0.1 \mathrm{~mm} \cdot \mathrm{d}^{-1}$. The drainage rate curve predicts that equilibrium will be reached at about 25 days after drainage starts, i.e. when the water content of the root zone is $323 \mathrm{~mm}$. If the same procedure is followed with a crop on this soil, a considerable fraction of the water draining through the soil will be extracted by the crop roots, to supply the ET demand ( 3.5 $\left.\mathrm{mm} \cdot \mathrm{d}^{-1}\right)$ in this example, while drainage is taking place. The result is that equilibrium is reached after about 2 days. The value of this principle is important for irrigation scheduling. Consider the situation with the water content of the root zone at $250 \mathrm{~mm}$ and one wants to irrigate. The assumption that $D U L$ is $323 \mathrm{~mm}$ permits an irrigation amount of $73 \mathrm{~mm}$ to avoid losses by deep drainage, whereas in fact an application in the case of this example of $123 \mathrm{~mm}$ is permissible. This adapted $D U L$ value was termed the 'crop modified upper limit of available water' or CMUL by Hensley et al. (2000).

\section{The lower limit of available water}

Reliable specification of the lower limit of available water is particularly important under irrigation. Irrigation scheduling using too low a value (i.e. underestimating the capacity of $\Delta S$ in Fig. 2) will result in the wastage of water, whereas using too high a value will result in waiting too long before applying water, resulting in excessive crop stress. Many WRC research workers have studied this subject. An example is given here (Fig. 4) of results obtained by Hensley and de Jager (1982). 'Field capacity' was determined from a drainage-curve procedure. In the results section the authors warn against accepting the traditional method of determining plant available water, i.e. water held between a matric suction value of $10 \mathrm{kPa}$ and a value somewhere between $10 \mathrm{kPa}$ and $1500 \mathrm{kPa}$, the latter to represent 'first material stress' (FMS). FMS was defined by Hensley and de Jager (1982) as the water content of the root zone when water needs to be added to avoid crop yield depression. The values of root-zone available water produced by the 2 procedures are $142 \mathrm{~mm}$ and $94 \mathrm{~mm}$ for the field and matric suction-curve procedures, respectively. 
(a)
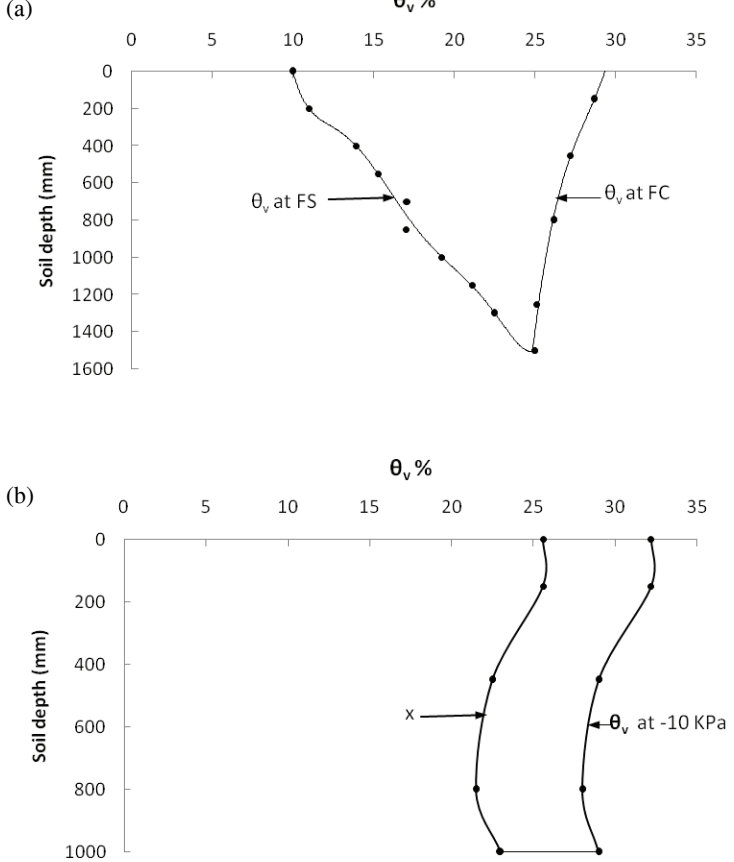

Figure 4

Actual and postulated soil-water extraction patterns for mature maize on Jozini series at Fort Hare farm:

a) Actual pattern based on means from 16 field determinations; $F C=$ field capacity, FMS = first material stress (=FS in the figure)

b) Pattern postulated by the matric suction curve (MSC) method

for estimating profile available water capacity; $x=\theta_{v}$ midway between $\theta_{v}$ at $-10 \mathrm{kPa}$ and $\theta_{v}$ at $-1500 \mathrm{kPa}$.

In the introduction it is stated that the sections 'Quantifying the water flow processes in SPAC' (previous section), and 'Managing rainfall and runoff' (next section), focus on past research results that serve as 'signposts for the way ahead'. These are the reasons:

- It is inevitable that the demand for food in South Africa will continually increase in the future, as will the priority demand for water for municipal and industrial uses, thereby reducing the amount available for irrigation. Rain-fed agriculture will therefore have to play a major role in increasing crop production to meet the growing demand for food.

- Schoeman and Scotney (1987) present an estimate of the rain-fed crop production potential of the commercially farmed area of South Africa, giving a total arable area of $14.27 \times 10^{6}$ ha with $7.00 \times 10^{6}$ ha and $4.14 \times 10^{6}$ ha described as having medium or low potential, respectively. On a large portion of this, namely $11 \times 10^{6}$ ha ( $78 \%$ of the total), the problem is rainfall deficiency, and therefore the area on which efficient water management will be of crucial importance to meet the growing need described above.

- Efficient water management can be enhanced by the effective use of crop models - the aim of the project by Bennie et al. (1998), in which the water balance model developed by Bennie et al. (1988) was employed. The procedure used in that model for quantifying the water supply rate of the root zone of a specific crop ecotope has a sound scientific basis. Much of the criticism about the procedures used to determine some of the coefficients can be overcome by using appropriate modern technology, e.g. measurement of soil water content at all depths with in situ instruments that record continuously. It seems that crop models in the past have not been constructed to cope efficiently with 'difficult' soils and root zones that become extremely dry - like so many sometimes do in the very large portion of South Africa's arable land. We believe that much could be gained by improving a current model, or combination of models, in every possible way to cope with these harsh conditions. The approach employed by Bennie et al. (1988) to deal with root-water extraction rate seems promising. Reliable definition of the upper and lower limits of available water is also important. The model should be able to predict yields with reasonable accuracy on all South African semi-arid crop ecotopes, however marginal. Such a project should receive a high priority in the effort to meet the inevitable challenge described above. The strategy with regard to such a project should include the careful selection of benchmark ecotopes to maximise the extrapolation efficiency of the results obtained.

\section{Managing rainfall and runoff}

\section{Rainfall management strategies with conventional tillage}

The projects of Bennie et al. (1997) and Bennie et al. (1994) produced valuable results. It was demonstrated that:

- Longer fallow periods between crops on particular ecotopes resulted in more pre-plant water in the root zones, promoting reduced risk of crop damage by seasonal droughts, and up to $30 \%$ higher yields and rainfall use efficiency (the latter expressed as $\mathrm{kg} \cdot \mathrm{ha}^{-1} \cdot \mathrm{mm}^{-1}$ )

- Deficit irrigation, compared to normal irrigation, increased rain-storage capacity in soils and reduced drainage losses from heavy rains after irrigations.

\section{In-field rainwater harvesting}

This strategy aims to manage rainfall and runoff. The design (Fig. 5) was developed specifically for subsistence farmers on marginal semi-arid crop ecotopes with high-drought-risk clay and duplex soils and high runoff losses (Hensley et al., 2000). Field experiments were initially carried out at the semi-arid Glen Experimental Station (Free State Province, South Africa) on these specific soils to test the viability of the technique. No-till on the runoff strip soon results in crust formation there; this enhances runoff which becomes stored in the basins and frequently percolates fairly deep into the soil beyond the zone most seriously influenced by Es. Placing mulch in the basins, suggested originally by Bennie et al. (1994) enhances this process by stimulating micro-organism activity, improving fertility status, and because of these, promotes the deep infiltration needed to cope with the above-normal amount of water accumulating there. Fairly deep soils ( $>900 \mathrm{~mm}$ preferably) with a high water storage capacity are needed for this strategy. Good results, with sunflower and maize yield increases of between $30 \%$ and $50 \%$ compared to yields achieved with conventional tillage, have been obtained with the technique at Glen and Thaba Nchu (Free State Province) on soils of the Bonheim, Swartland and Arcadia forms (Soil Classification Working Group, 1991).

It is difficult to model crop growth using this system because of its relative complexity compared to the system shown in Fig. 2. To cope with the complexity, and on his own initiative, J.J. Botha developed an empirical model called CYP-SA (Crop Yield Prediction for Semi-Arid Areas). Complete details regarding the model are presented in Botha 


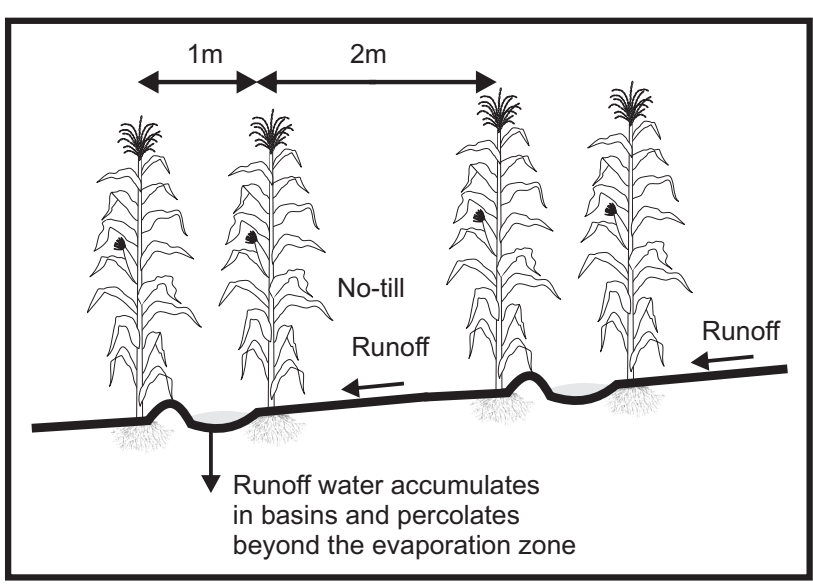

Figure 5

The no-till in-field runoff water-harvesting technique, with mulch in the basins (Hensley et al., 2000)

(2006). The model was calibrated and validated against measured yields (Botha et al., 2003). Some results obtained using the model together with long-term Glen climate data are presented in Fig. 6. The long-term benefit of IRWH, compared to conventional tillage is clearly demonstrated in Fig. 6(a). The value of the model for doing theoretical long-term experiments to test hypotheses regarding the value of different management strategies is demonstrated by the results shown in Figs. 6(b) and 6(c).

- With WRC funding provided over the past 15 years it has been possible to expand the IRWH work and it is now being carried out in 3 provinces. Particularly important aspects are the associated capacity building, extension activities, socio-economic studies, and impact assessments. These are dealt with to some extent in all IRWH reports, but more specifically in the following: Kundhlande et al. (2004); Hensley et al. (2007); Botha et al. (2007); Manona and Baiphethi (2008); Blignaut and Sibande (2008).

- The urgent need to improve the productivity of communal croplands of subsistence farmers in South Africa is well described by Backeberg (2009). He emphasises the valuable role that water conservation tillage techniques like IRWH could play to achieve this objective. Here then is another of the 'signposts for the way ahead' referred to in the introduction to this review.

\section{Conclusions and recommendations}

This review shows that a great deal has been learnt during the past 36 years about water flow processes in the soil-plantatmosphere continuum (SPAC), represented in the landscape by different ecotopes. The focus has been on the management of the processes in the soil under dryland and irrigated conditions. An indication of the level of understanding that has been achieved is demonstrated by the fact that it has been possible to quantify the important processes in several mathematical models. In particular, the 3 computer models, BEWAB, SWAMP and CYP-SA, have successfully demonstrated proficiency and have been applied in practice and research.

It is difficult to assess the impact of this work on agricultural production in South Africa. However, the continued ability of South African farmers to produce adequate food and fibre from a relatively unfavourable resource base is strong evidence that improved production techniques, which are inevitably (a)

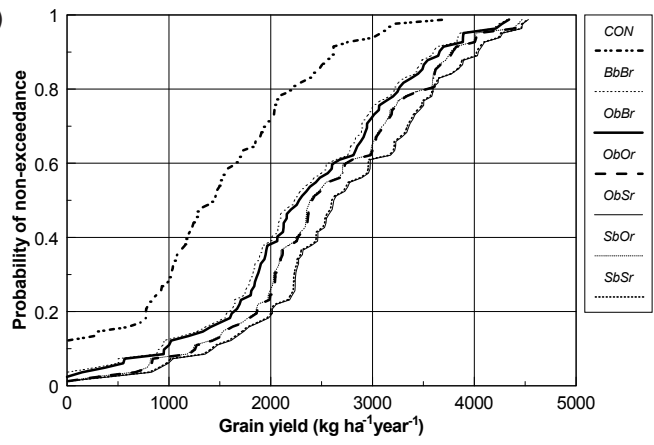

(b)

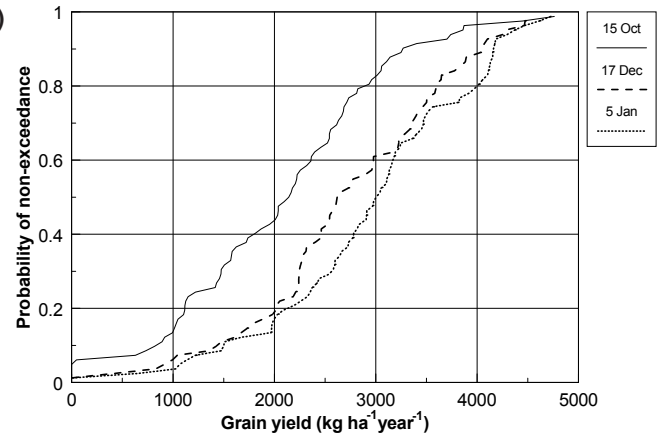

(c)

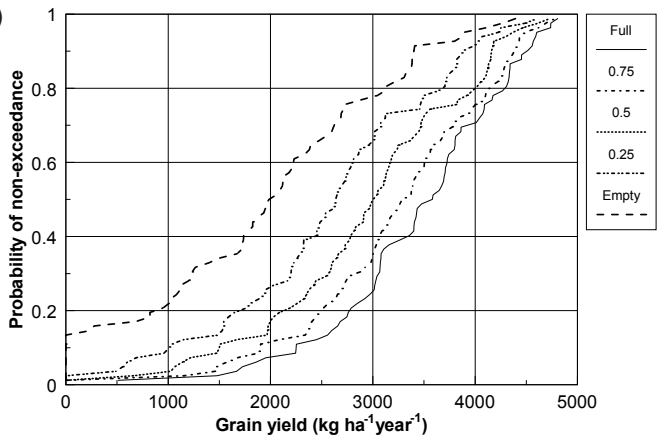

Figure 6

CPF graphs of long-term maize yields simulated with CYP-SA (maize) on the Glen/Bonheim - Onrus ecotope: (a) different tillage techniques, $\theta_{p}=1 / 2$ full, planted on 17 December; (b) ObSr tillage technique, $\theta_{p}=1 / 2$ full, using 3 planting dates; (c) ObSr tillage technique, planting 5 January with 5 different $\theta_{p}$ values. Climate data used are for the 81-year period 1922-2003.

In Fig. 6a six different IRWH treatments are recorded, each one with different treatments to the basin or runoff strip; the best one, ObSr, had mulch in the basins and stones on the runoff strip (Fig. 5)

berthed by work like this, have made a significant contribution. It is expected that the impact of IRWH and similar waterconservation techniques could be huge if wisely applied on the croplands of subsistence farmers.

The research has resulted in much capacity building; 58 researchers and a number of technical assistants have been involved in the 27 projects included in this review. Of these, 21 researchers started their research careers on WRC-funded projects.

The following are considered to be important research and development needs:

- Improved understanding of plant-adaption mechanisms when the soil-water status reaches the lower limit of the plant available water in the root zone.

- An integrated approach towards simultaneously optimising soil water and nutrient use by crops in dry areas for greater efficiency and sustainability. 
- A crop model capable of dealing effectively with the harsh climates and 'difficult' soils so common in the semi-arid, and particularly the dry semi-arid areas of South Africa, i.e. the dryland crop ecotopes that constitute such a large fraction of our arable land.

- Ex-field rainwater harvesting is a crop production technique which is as yet virtually unused in South Africa. It holds considerable potential for improving crop production in dry semi-arid areas. Suitable sites on communal land near Thaba Nchu have been identified and the expertise needed for the research is available.

- Appropriate procedures for the expansion of IRWH to the croplands of subsistence farmers in semi-arid areas.

\section{Recognition and acknowlegements}

The powerful role played by the Water Research Commission with regard to encouraging, funding and efficient monitoring of this research work cannot be overemphasised. This organisation has made a very important contribution to South African agriculture throughout the past 40 years.

\section{References}

BACKEBERG GR (2009) Improving rural livelihoods with rainwater harvesting and conservation on communal croplands in South Africa: Opportunities and obstacles. Proc. $2^{\text {nd }}$ International Seminar of the International Foundation for Sustainable Development in Africa and Asia, 14 to 16 July 2009, Göttingen, Germany.

BENNIE ATP, COETZEE MJ, VAN ANTWERPEN R and VAN RENSBURG LD (1988) 'n Waterbalansmodel vir Besproeiing Gebaseer op Profielwater-voorsieningstempo en Gewas Waterbehoeftes (A Water Balance Model for Irrigation Based on the Water Supply rate from the Soil Profile and Crop Water Demand). WRC Report No. 144/1/88. Water Research Commission, Pretoria, South Africa. 114 pp.

BENNIE ATP, HOFFMAN JE, COETZEE MJ and VREY HS (1994) Opgaring en Benutting van Reënwater in Grond vir die Stabilisering van Plantproduksie in Halfdroë Gebiede (The Storage and Use of Rain Water in Soil for Stabilizing Crop Production in Semi-Arid Areas). WRC Report No. 227/1/94. Water Research Commission, Pretoria, South Africa. 208 pp.

BENNIE ATP, VAN RENSBURG LD, STRYDOM MG and DU PREEZ CC (1997) Reaksie van Gewasse op Voorafgeprogrammeerde Tekortbesproeiing (The Reaction of Crops to PreProgrammed Deficit Irrigation). WRC Report No. 423/1/97. Water Research Commission, Pretoria, South Africa. 225 pp.

BENNIE ATP, STRYDOM MG and VREY HS (1998) Gebruik van Rekenaarmodelle vir Landboukundige Waterbestuur op Ekotoopvlak (The Use of Computer Models for Agricultural Water Management at Ecotope Level). WRC Report No. TT102/98. Water Research Commission, Pretoria, South Africa. 235 pp.

BLIGNAUT J and SIBANDE X (2008) Assessing the Impact of Fifteen Years of WRC-Funded Research in Thaba Nchu. WRC Report No. TT 444/08. Water Research Commission, Pretoria, South Africa. 97 pp.

BOEDT LJJ and LAKER MC (1985) The Development of Profile Available Water Capacity Models. WRC Report No. 98/1/85. Water Research Commission, Pretoria, South Africa. 450 pp.

BOTHA FJP, BENNIE ATP and BURGER R DU T (1983) Water Use Efficiency of Irrigated Crops as Influenced by Varying Cultivation Practices and Root Configurations. Dept. Soil. Sci., UFS, Bloemfontein, South Africa. 391 pp.

BOTHA JJ, VAN RENSBURG LD, ANDERSON JJ, HENSLEY M, MACHELI MS, VAN STADEN PP, KUNDHLANDE G, GROENEWALD DG and BAIPHETHI MN (2003) Water Conservation Techniques on Small Plots in Semi-Arid Areas to Enhance Rainfall Use Efficiency, Food Security and Sustainable
Crop Production. WRC Report No. 1176/1/03. Water Research Commission, Pretoria, South Africa. 323 pp.

BOTHA JJ (2006) Evaluation of Maize and Sunflower Production in A Semi-Arid Area using In-Field Rainwater Harvesting. Ph.D. dissertation, University of the Free State, Bloemfontein, South Africa. $287 \mathrm{pp}$.

BOTHA JJ, ANDERSON JJ, GROENEWALD DC, NHLABATSI NN, MDIBE N, BAIPHETI MN and ZERE TB (2007) On-Farm Application of In-Field Rainwater Harvesting Techniques on Small Plots in the Central Region of South Africa. WRC Report No. 52/056. Water Research Commission, Pretoria, South Africa. 198 pp.

BURGER R DU T, BENNIE ATP, BOTHA FJP and DU PREEZ CC (1979) Grondverdigting onder Besproeiing op die Vaalhartsbesproeiingskema: Vol 1. Samevattende Verslag (Soil Compaction under Irrigation on the Vaalharts Irrigation Scheme: Vol 1. Summarising Report 1979). Report No. 79/1. Dept. Soil. Sci., UFS, Bloemfontein, South Africa. 140 pp.

DENT MC, SCHULZE RE and ANGUS GR (1988) Crop Water Requirements, Deficits and Water Yield for Irrigation Planning in Southern Africa. WRC Report No. 118/1/88. Water Research Commission, Pretoria, South Africa. 183 pp.

EHLERS L, BENNIE ATP and DU PREEZ CC (2003) The Contribution of Root Accessible Water Tables Towards the Irrigation Requirements of Crops. WRC Report No. 1089/1/03. Water Research Commission, Pretoria, South Africa. 148 pp.

EHLERS L, BARNARD JH, DIKGWATLHA SB, VAN RENSBURG LD, CERONIO GM, DU PREEZ CC and BENNIE ATP (2007) Effect of Irrigation Water and Water Table Salinity on the Growth and Water Use of Selected Crops. WRC Report No. 1359/1/07. Water Research Commission, Pretoria, South Africa. 166 pp.

HENSLEY M and DE JAGER JM (1982) The Determination of the Profile Available Water Capacities of Soils. Department of Soil Science, University of Fort Hare, Alice, South Africa. 282 pp.

HENSLEY M, ANDERSON JJ, BOTHA JJ, VAN STADEN PP, SINGELS A, PRINSLOO M and DU TOIT A (1997) Modelling the Water Balance on Benchmark Ecotopes. WRC Report No. 508/1/97. Water Research Commission, Pretoria, South Africa. 130 pp.

HENSLEY M, BOTHA JJ, ANDERSON JJ, VAN STADEN, PP and DU TOIT A (2000) Optimizing Rainfall Use Efficiency for Developing Farmers with Limited Access to Irrigation Water. WRC Report No. 878/1/00. Water Research Commission, Pretoria, South Africa. 131pp.

HENSLEY M, LE ROUX PAL, GUTTER J and ZERIZGHY MG (2007) A Procedure for an Improved Soil Survey Technique for Delineating Land Suitable for Rainwater Harvesting. WRC Report No. TT 311/07. Water Research Commission, Pretoria, South Africa. 113 pp.

HUMAN JJ, DE BRUYN LP and SPAMER MJM (1980) Die Invloed van Plantvogstremmings op die Groei en Produksie van Sekere Akkergewasse (The Influence of Plant Water Stress on the Growth and Productivity of Selected Agronomic Crops). Department of Agronomy, University of the Free State, Bloemfontein, South Africa. $187 \mathrm{pp}$.

KUNDHLANDE G, GROENEWALD DG, BAIPHETHI MN, VILJOEN MF, BOTHA JJ, VAN RENSBURG, LD and ANDERSON JJ (2004) Socio-Economic Study on Water Conservation Techniques in Semi-Arid Areas. WRC Report No. 1267/1/04. Water Research Commission, Pretoria, South Africa. 241 pp.

MACVICAR N, SCOTNEY DM, SKINNER TE, NIEHAUS HS and LAUBSER JH (1974) A classification of land (climate, terrain form, soil) primarily for rainfed agriculture. S. Afr. J. Agric. Ext. 3 22-24.

MANONA S and BAIPHETHI MN (2008) Developing a Land Register and a Set of Rules for Application of Infield Rainwater Harvesting in Three Villages in Thaba Nchu. WRC Report No. TT 367/08. Water Research Commission, Pretoria, South Africa. 51 pp.

MEYER WS, OOSTERHUIS DM, BERLINER PR, GREEN GC and VAN DER MERWE AJ (1987) Evapotranspiration and Water Use Studies in Wheat and Soybeans with the Help of the Weighing Lysimeter Technique. WRC Report No. H2/1/87. Water Research 
Commission, Pretoria, South Africa. 62 pp.

NEL PC, FISCHER HH, ANNANDALE JG and STEYNBERG RE

(1986) Waterbehoeftes van Drie Akkerbou- en Drie Groentegewasse (Water Requirements of Three Agronomic crops and Three Vegetable Crops). WRC Report No. 84/1/86. Water Research Commission, Pretoria, South Africa. 206 pp.

RAO SC, STEINER JL and MAYEUX HS (2004) The role of world's agricultural lands for future food security. In: Rao SC and Ryan J (eds.) Challenges and Strategies for Dryland Agriculture. Crop Science Society of America, Special Publication 32, Madison, Wisconsin.

RATLIFF LF, RITCHIE JT and CASSEL DK (1983) Field-measured limits of soil water availability as related to laboratory-measured properties. Soil Sci. Soc. Am. J. 47 770-775.

RUSSELL DA (1982) Determination of Important Physical and Chemical Soil Parameters in Relation to Irrigation and Drainage. Department of Soil Science, University of Fort Hare, Alice, South Africa. 238 pp.

SCHOEMAN JL and SCOTNEY DM (1987) Agricultural potential as determined by soil, terrain and climate. S. Afr. J. Sci. 83 260-268.

SOIL CLASSIFICATION WORKING GROUP (1991) Soil Classification: A Taxonomic System for South Africa. Department of Agricultural Development, Pretoria, South Africa.

UNESCO (1977) World Map of Desertification. United Nations Conference on Desertification Report 74/2. United Nations, New York.

VAN DEVENTER PW, BENNIE ATP and HATTINGH JM (2002) Hydraulic Properties of Stony Soils. WRC Report No. 725/1/02. Water Research Commission, Pretoria, South Africa. 72 pp.

VAN ZYL WH and DE JAGER JM (1997) Estimation of Plant and Soil Evaporation from Cropped Lands. WRC Report No. 507/1/97. Water Research Commission, Pretoria, South Africa. 87 pp.

VANASSCHE FMG and LAKER MC (1989) Studies on Irrigation Management Based on PAWC and Soil Water Monitoring. WRC Report No. 166/1/89. Water Research Commission, Pretoria, South Africa. 492 pp.

WALKER S, FYFIELD TP, McDONALD JPA and THACKRAH A (1995) The Influence of Different Water and Nitrogen Levels on Crop Growth, Water Use and Yield, and the Validation of Crop Models. WRC Report No. 307/1/95. Water Research Commission, Pretoria, South Africa. $214 \mathrm{pp}$

WALKER S and TSUBO M (2003) PUTURUN: A Simulator of Rainfall-Runoff-Yield Processes with In-Field Water Harvesting. WRC Report No. KV142/03. Pretoria, South Africa. 21 pp. 
http://dx.doi.org/10.4314/wsa.v37i5.14 Available on website http://www.wrc.org.za

ISSN 0378-4738 (Print) = Water SA Vol. 37 No. 5 WRC 40-Year Celebration Special Edition 201 ISSN 1816-7950 (On-line) = Water SA Vol. 37 No. 5 WRC 40-Year Celebration Special Edition 2011 